\title{
Datafication in schools : Enactments of quality assurance and evaluation policies in Brazil
}

\section{Hinke Dobrochinski Candido, Helena}

2020-04-02

Hinke Dobrochinski Candido , H 2020 , ' Datafication in schools : Enactments of quality assurance and evaluation policies in Brazil ' , International Studies in Sociology of Education , vol. 29 , no. $1-2$, pp. 126-157 . https://doi.org/10.1080/09620214.2019.1656101

http://hdl.handle.net/10138/328025

https://doi.org/10.1080/09620214.2019.1656101

unspecified

acceptedVersion

Downloaded from Helda, University of Helsinki institutional repository.

This is an electronic reprint of the original article.

This reprint may differ from the original in pagination and typographic detail.

Please cite the original version. 


\title{
Datafication in schools: enactments of quality assurance and evaluation policies in Brazil
}

\author{
Helena Hinke Dobrochinski Candido ${ }^{\text {a* }}$ \\ ${ }^{a}$ Faculty of Educational Sciences, University of Helsinki, Helsinki, Finland \\ *corresponding author: helena.candido@ helsinki.fi
}

To cite this article: Candido, H. H. D. (2019) Datafication in schools: enactments of quality assurance and evaluation policies in Brazil. International Studies in Sociology of Education, 29(1-2), 126-157. DOI: 10.1080/09620214.2019.1656101

Funding details: This work was supported by the Academy of Finland under grants n. 273871 and 307310.

Disclosure statement: No potential conflict of interest is reported by the author.

Acknowledgements:

I am thankful for discussing a preliminary version of this paper in the CIES 2018 publication workshop, coordinated by D. Brent Edwards and Sandra L. Stacki. I am very grateful for the thorough comments I received from Sirpa Lappalainen and Janne Varjo, which immensely contributed to the final version of this article.

Helena Hinke Dobrochinski Candido is a post-doctoral researcher in the Faculty of Educational Sciences, University of Helsinki, Finland. She holds a PhD in Political Sociology and a Master's degree in Regional Development. Her main research interest lies in education politics. She is particularly concerned with large-scale assessments and indicators as source of evidence for policymaking, the interface of public and private actors in education governance, and marketization in education. Her primary geographical focuses of research are Brazil and Finland. 


\section{Datafication in schools: enactments of quality assurance and evaluation policies in Brazil}

This paper investigates datafication in schools through an analysis of the enactments of quality assurance and evaluation (QAE) policies in Brazil. In doing so, I question how data permeates and changes school environments, school actors' conduct and their imaginaries. QAE policies encompass large-scale assessments, indicators, rankings and other steering mechanisms, but importantly connect data to quality in education. Here, I analyse the discourses of school actors (principals, coordinators, supervisors, teachers, students and parents) from three Brazilian public schools collected through semistructured interviews $(n=28)$. Data manifests in those schools as a technology of government. Schools enact QAE policies in distinct ways, incorporating the idea of governmentality, but also proposing alternative patterns of action.

Keywords: Datafication; quality assurance and evaluation (QAE); policy enactment; schools; school actors; Brazil.

\section{Data in Brazilian basic education: quality assurance and evaluation policies}

Since the late 1980s, Brazil, along with other developing countries, has followed the international education agenda (UNESCO, 2004), which shifts the political focus from school access to quality measurement (Oliveira \& Araujo, 2005). This shift was influenced by a 'scientific rationality' (Steiner-Khamsi, 2003), aligning the measurement of quality in education with economic growth (Carnoy et al., 2015). Within such an economic development orientation, efficiency in education requires data ${ }^{1}$ gathering, to which quality became closely related.

\footnotetext{
${ }^{1}$ Data is referred as a construct in this article, 'as an object vested with certain powers, influence, and rationalities' (Rupert et al., 2017:1). It is a ubiquitous term, associated to numbers, statistics, and digitalisation. An object of knowledge as well as an object of power (Rupert et al., 2017), data affects those for whom it is designed and directed (Hardy, 2015).
} 
Education data production in Brazil dates to the beginning of the 20th century. It intensified in the 1980s until now (Kauko et al., 2016), counterbalancing the decentralisation associated to the New Public Management (NPM) ideas flourishing in the country at that time (Candido, 2018). The yearly national school census, for instance, collects data of over 27 million basic education ${ }^{2}$ students and 128 thousand schools (INEP, 2018). Every other year, national large-scale assessments (LSAs) evaluate around 5,4 million students' performance in Math (Problem Solving) and Portuguese language (Reading) (INEP, n.d.). In addition, a great number of Brazilian federal entities (states and municipalities) hold their own education data gathering mechanisms.

The first LSA took place in 1990: the National Basic Education Assessment System (Sistema de Avaliação da Educação Básica - SAEB). Debuting as a single national LSA, it now consists of three external bi-annual assessments: the National Assessment of Literacy (Avaliação Nacional da Alfabetização - ANA), the National Assessment of Basic Education (Avaliação Nacional da Educação Básica - Aneb) and the National Assessment of School Performance (Avaliação National do Rendimento Escolar - Anresc), popularly known as Prova Brasil. ${ }^{3}$ SAEB primarily aims to assess the quality, equity and efficiency of Brazilian

${ }^{2}$ In this paper, I adopted the definition of basic education provided by the International Standard Classification of Education (UNESCO, 2012) despite the fact that Brazilian basic education includes the early-childhood ('educação infantil') and high school ('ensino médio') levels of education, which are all compulsory in Brazil. In Brazilian terminology, this study concentrates on 'ensino fundamental'.

${ }^{3}$ ANA is applied to all primary public-school students in the second grade; Aneb assesses a sample of low-secondary education students in the fifth and ninth grades and in the third grade in uppersecondary public and private institutions; and Prova Brasil covers all public-school students enrolled in the fifth and ninth grades. 
basic education and to diagnose problems in students' achievements. SAEB also intends to increase participation in education across the whole of society, through transparency and accountability aligned to data. Students' scores on Aneb and Prova Brasil, along with school progression, are used to calculate the Basic Education Development Index (Índice de Desenvolvimento da Educação Básica - IDEB), established in 2007 to measure quality in education at the school, municipality, state and national levels.

The federal government operates SAEB, relying on cooperation between sub-national entities for its implementation, and setting IDEB's targets for education in the national, state, municipal and school levels ${ }^{4}$ (Candido, 2018). Through the decentralised education system, SAEB and IDEB data are expected to facilitate the local management of education at the subnational government and school levels (Machado \& Alavarse, 2014), despite rhetorical autonomy of such federal entities (Candido, 2018). Moreover, national education programmes, as the National Pact for Literacy at the Proper Age (Pacto Nacional pela Alfabetização na Idade Certa - PNAIC) and the Interactive School Development Plan (Plano de Desenvolvimento da Escola Interativo - PDDE Interativo), as well as sub-national programs, contribute to data production in Brazilian education.

A literature review on quality and evaluation in Brazilian education revealed criticism of both the means and the ends of such data infrastructure (Candido \& Lappalainen, submitted). Yet, little attention has been devoted to how school actors incorporate the policies related to quality and evaluation in education. The international literature suggests that

\footnotetext{
${ }^{4}$ IDEB's targets are aligned to OECD's PISA (Kauko et al, 2016). Specifically, no Brazilian state achieved the national targets for IDEB for upper-secondary education in 2017, only 7 of 27 federal entities reached the lower-secondary education targets and 24 states met the IDEB targets for primary education (INEP, 2018). In addition, Brazil's position in the PISA rankings has remained low since 2000 .
} 
policies resonate in distinct manners at the school level (Gurova et al, 2018; Maroy et al., 2017; Hardy, 2015; Braun et al., 2011; Coburn, 2004; Tyack \& Cuban, 1995), often in ways different to policymakers' outlines. Whilst this phenomenon has been widely studied in Anglo-American and European countries, it remains under-examined in the Global South. Thus, this study attempts to fill this gap by exploring the enactments of quality assurance and evaluation (QAE) policies in Brazilian schools. Specifically, I aim to understand how data permeates and changes school environments, school actors' conduct and their imaginaries through the engagement of the Brazilian case in dialogue with European and other nonEuropean countries in this Special Issue.

The two sections that follow introduce the theoretical background of this research. Firstly, I define the main concepts: datafication and QAE. Secondly, I provide theoretical reflections about policy enactment, since this work examines the political character of data in education. Then, I describe the research design. In this study, I analysed the discourse from 28 interviews with school actors from three Brazilian public schools, supplemented by a literature review, document analysis and observations. ${ }^{5}$ Next, I present and discuss the main findings of the discourse analysis, which are associated with school actors' understandings of QAE policies, their engagement with such policies and the effects of QAE policy enactments at the school level. Finally, I provide a concluding section, in which I review the primary ideas about datafication in Brazilian schools, outline the limitations and implications of this research and suggest possibilities for a deeper understanding of the phenomenon under scrutiny.

\footnotetext{
${ }^{5}$ The research data were gathered within the project 'Transnational Dynamics in Quality Assurance and Evaluation Politics of Basic Education in Brazil, China and Russia (2014-2017)', funded by the Academy of Finland (grants nos. 273871 and 307310).
} 


\section{Quality assurance and evaluation policies as a means of datafication}

Lawn (2011) argues that data is central to modern governance. The use of data for governing is embedded in a 'calculative rationality' (Bauman, 1992) within 'statistics', the science of the state (Foucault, 1991). Such use is a political choice, since data is constructed allowing for the categorisation, politicisation, and regulation of abstract entities, making them easier to govern (Erkkilä \& Piironen, 2009; Lawn, 2011).

Data is framed through the cultural narrative granting objectivity, certainty and impartiality to both objective and abstract aspects of life, whilst diminishing subjective and biased interpretations of different phenomena (Williamson, 2017). As such, data possesses an authority for decision-making (Hardy, 2015). It is taken for granted that data makes things more visible (through data visualisation and transparency), knowable and explainable (through data production and circulation) as well as controlled (through data steering systems). Such instrumentality is amenable to certain forms of action and intervention (Williamson, 2017), delimiting relevance. Such delimitations, however, are not as visible as data, since they rely on the arbitrary lenses of the data designer. Data becomes entities supporting descriptions of the world and ways of acting upon them (Desrosières, 1998) based on discursive choices.

Data has no value without discourses (Besson, 1995; Popkewitz \& Lindblad, 2001), which, in turn, are enacted through data (Ruppert et al., 2017). Therefore, data produces different versions of reality, distinct conventions and normative frames, without necessarily revealing the social and political struggles embedded in its creation. Data represents power (Ruppert et al., 2017), connecting people, processes and objects in relation to power, and establishing a diffuse network of blurred positions, which suits different governing purposes (Piattoeva, 2015). As such, data is biased, confined to the grounds supporting its production, and its understanding should remain associated to the context where it originated (Jarke \& 
Breiter, 2019). Data reflects presuppositions, rather than reality; offers clues about certain issues, rather than truth; and leads to plausibility, rather than certainty (Gatti, 2004). The combination of data and discourse(s) constitute a particular set of rationality, referred to in this article as datafication - that is, ways of seeing, understanding and engaging with the world through data (Williamson, 2017).

Data is used as a technology of government (Miller \& Rose, 1990; Rose \& Miller, 1992), making people and processes more visible and, thus, enabling control and normalisation (Piattoeva, 2015). Simultaneously, data make some processes invisible, since the ends often prevail over the means. The 'umbrella concept' (Centeno et al., 2018) of quality assurance and evaluation (QAE) conceptually incorporates the production and circulation of data in education (Piattoeva et al., 2018). Data is used to improve schools and education, to hold schools and teachers accountable, to control school access and progress, to reward and punish schools and school staff and to compare student achievements across schools, municipalities, regions (states, provinces) and countries (Jarke \& Breiter, 2019). The dissemination of QAE as a technology of government and as a means of governance at a distance is facilitated by the 'authoritative "seal of approval"' (Löwenheim, 2008:263) of evaluations and quality indicators.

The governance shift in education (Ozga, 2009), manifested through 'governing by numbers' (Grek, 2009) and 'governance through data' (Lawn, 2011), understands QAE as a powerful strategy and governance tool in education politics (Simola et al., 2009; Ozga et al., 2011). QAE not only encompasses evaluations and quality indicators, but also planning, auditing, inspection and regulation, permeating the entire process of data production and management. Rankings, ratings, indicators, indices and reports based on QAE policies serve as key steering tools to modulate policymaking (Lingard et al. 2016; Nóvoa \& Yariv-Mashal, 2003). Such mechanisms are not neutral (Lascoumes \& Le Galès, 2007), since 'evaluation is 
a policy instrument' (Ozga, 2009:150). Furthermore, QAE policies set and enforce standards in education, legitimising rewards and punishments by government authorities.

QAE policies act as indirect intervention, sustaining the state's soft governance in education, whereas comparability stands at its symbolic feature and mode of operation (Ozga, 2009; Nóvoa \& Yariv-Mashal, 2003). As such, they implicitly emphasise constant selfregulation and self-improvement within school environments and actors (Lawn \& Grek, 2012; Ozga, 2009), supported by the idea of governmentality (Foucault, 1991). Thus, QAE policies corroborate the construction of truth within a hierarchy of knowledge, delimiting the boundaries of rational and correct conduct (Löwenheim, 2008). This means that QAE is a non-neutral policy instrument of governance and the data produced by QAE policies fills the space between the state and the new user-consumer citizen (Ozga, 2009).

Having multiple facets, QAE policies do not represent a single mode of governance, but permeate different models (Gurova et al., 2018). They incorporate the principle of standardisation from the 'bureaucratic-professional' model of governance (Maroy, 2009), embedded in Weber's (2015) ideas of efficiency and rationality organising and maintaining social order. QAE policies also embody the entrepreneurial spirit of NPM, emphasising the control of outcomes, creating networks, reshaping actor relations and their roles in governing education, regulated by accountability regimes, performance management and evaluation. Additionally, QAE relies on expertise and data infrastructures (Lawn \& Segerholm, 2011), reinforcing 'governance at a distance', in which actors share a significant degree of autonomy based on their willingness to engage in education processes (Miller \& Rose, 1990). This reduces the likelihood of resistance to governance measures (Kickert, 1995).

Technologies of government make policies operable (Piattoeva, 2015), 'bringing new issues to the fore, allowing these to become desired goals, guidelines or deficiencies of governing, but also narrowing room for debate' (Erkkilä \& Piironen, 2009:129). The 
discursive use of 'quality', a ubiquitous term entailing a positive connotation in evaluating education within the QAE terminology, glamorises as well as creates high expectations concerning datafication in education. Quality is the ideal goal, whereas QAE policies become the concrete means, and data emerges as the end, or the outcome, of such dynamics, in a cycle that feeds political acts of governing.

QAE policies, therefore, consist of key governance tools in education, functioning as means of datafication. Immersed in governmentality (Foucault, 1991), such policies contribute to the art of governing through the dissemination of particular mentalities and mindsets (Löwenheim, 2008). Individual conduct, thoughts, decisions and aspirations are shaped, normalised, disciplined and governed through QAE mechanisms to achieve the desired political goals. However, in order to further understand those processes, it is necessary to understand how policies reach schools, that is, how they are enacted in schools. This is the topic of the next section.

\section{Policy enactment in schools}

Schools are organic entities and not necessarily coherent organisations. As such, overlapping interests, competitiveness and tensions coexist alongside some sort of teamwork (Ball et al., 2012). School actors are 'subject to and objects of policy' (Ball et al., 2012:3), but also political actors (Gurova et al, 2018). Negotiation, contestation and struggles among school actors and in relation to different groups (e.g., government) form mechanisms of policymaking (Ozga, 2000).

Policy implementation goes beyond the normative and linear political process, since it cannot avoid the 'jumbled, messy, contested, creative and mundane social interactions' (Ball et al., 2012:2). Policy becomes relevant only when translated, that is, when the policy receives local meaning. This process is contested and challenged, given that the local 
meaning is refracted by actors' 'internal selection thresholds and needs for interpretation, which are the outcome of cultural traditions and collective mentality, as well as political forces and dominant ideologies' (Schriewer \& Martinez, 2004:50). Furthermore, actors are hardly passive. They resist, master an idea without appropriating it, deliberately redefine meanings offered or imposed by others, accept the meanings as they have been presented or create new ideas reflecting their own intellectual conviction (Anderson-Levitt, 2012).

The concept of policy enactment captures the social interactions and subjectivities inherent in the policy implementation process. Policy enactment refers to the idea that policies are interpreted and translated by actors rather than simply implemented (Braun et al., 2010; Ball et al., 2012). It encompasses the possibilities of policy acceptance, resistance and subversion within ad-hoc, borrowing, re-ordering, displacement, innovation, and re-invention processes.

Enactment is collective and collaborative, combining actors, technology, discourses and objects (artefacts) in on-going processes of negotiation, interpretation and translation, which can be durable, temporary or transitory, and assume a constantly changing nature of organisations and people. Policies are enacted based on rational-choice theory (personal interest or to maximise utility), sense-making schemas or individual, social and institutionally contextualised factors (Ball et al., 2012). Such context extends beyond the locality, culture, history, tradition, legal requirements, practices, actors' roles and discourses, professional expertise, available resources and school infrastructure, to encompass school actors' values and emotions. The latter includes the "clash of personalities, the dedication and commitment, the ambition and burn-out, the humour and the moments of cynicism and frustration' (Ball et al., 2012:5).

Therefore, policy enactment goes beyond implementation. In the study conducted by Ball et al. (2012), some policies were differently enacted within the same school by different 
policy actors; other policies were grouped into policy ensembles, mutually reinforcing each other; and a third set of policies collided or overlapped, causing contradictions, incoherence or confusion. Furthermore, they observed that school actors assume different positions, which vary at different stages during their careers and depend upon their accumulated experience, guiding their responses to policies in distinct ways. Moreover, some actors may be more dominant than others, or less influenced by particular policies than others (Maguire et al., 2015).

In general, policies constrain the range of options available, defining the situation and limiting the possibilities of action. Yet, they are contingent (Palonen, 2003); their effects produce unexpected and unintended second-order effects, changing schools, routines and practices, as well as relationships among peers. The ways policies manifest in schools emulate governance patterns from the surrounding context or create alternative governance regimes at the micro-level of schools (Gurova et al, 2018). Importantly, some spaces within schools remain untouched by policy.

In contrast to the concrete and visible effects of policies in schools, policy enactment may occur in subtle ways. Subjectification (Piattoeva, 2015), for instance, legitimises the policies and discourses they produce, as exemplified by Löwenheim (2008:258): 'the examiner constructs a new discourse of legitimacy that can be used to shape and guide examinees' conduct'. The 'disciplined' individuals show willingness to be tested and seriously take responsibility for positive and negative results; they do not perceive this as part of their disciplinary process. Alternatively, some school actors enact the policies as a 'counter-conduct' (Foucault, 2007) to the prevailing governance in education. 


\section{Research design: discourse analysis of Brazilian school actors}

The continental reach and complexity of Brazilian education, and the extensive comprehension of enactments of QAE policies this research aims to achieve guided the selection of a specific locality in which to conduct this research: the state of Santa Catarina, located in southern Brazil (6.2 million inhabitants). Santa Catarina has closely interacted with OECD, and is recognised as a frontrunner in PISA and IDEB. Its capital, Florianópolis, developed a local LSA called Prova Floripa, ${ }^{6}$ and recently received an Inter-American Development Bank (IDB) loan, which conditioned data production and its circulation for local education governance.

I investigated three public schools, ${ }^{7}$ funded and maintained by either the state of Santa Catarina or the municipal government of Florianópolis. ${ }^{8}$ The primary research data consist of 28 semi-structured thematic interviews in Portuguese with key school actors (school principals, coordinators, supervisors, teachers, ninth grade students and parents) in those schools, here referred to as School A, School B and School C. I also conducted observations for more than eight weeks in the selected schools. I observed school board meetings, teachers' meetings and trainings, school principal election processes, lessons, the

${ }^{6}$ The Prova Floripa was administered annually between 2007 and 2016. It was discontinued after the new municipal government took office in January 2017.

${ }^{7}$ Santa Catarina had more than 3119 basic education institutions in 2018. The majority were public, under the responsibility of any of the 295 municipalities (53.01\%), the state (32.67\%) or the federal government (0.04\%); only $14.27 \%$ were private. Enrolments reached 851993 in 2018 . Following the national level pattern, more than $80 \%$ of students attended public schools: $52.84 \%$ were enrolled in municipal schools, $34.18 \%$ in state schools; and $0.08 \%$ in federal schools. Private institutions had $12.90 \%$ of basic education students in Santa Catarina in 2018 (INEP, 2019).

${ }^{8}$ The characterisation of the schools is limited out of respect for the anonymity of research participants. 
administration of SAEB and interacted with school staff during formal and informal events during the time I spent in the schools. The observations supported the analysis of the school actors' interviews.

The selected schools are large with around 1000 students each, staffed by between 60 and 100 school personnel among whom around 50 are teachers. One of the schools offers upper-secondary along with primary and lower-secondary education, but the research focus remained on basic education (grades 1-9). Their students come from the catchment area of the three schools, corresponding to low- or lower middle-income households. The major problem faced by those schools, as described in the interviews, relates to a lack of resources, manifesting in low teacher salaries, poor school infrastructure and limited funding for enhancing students' learning experiences.

Yet, each of the three schools has its own particularities, reflecting their sociohistorical context. Respondents considered School A as different from other public schools. Specifically, they regard this school as a high-quality institution, since it offers additional courses (e.g., music) and workshops in partnership with a local university. In their view, School A better prepares students for the upper-secondary level when compared to other schools in the community. During my fieldwork, teachers from School A engaged in a strike, asking for a better career plan. The failed negotiations between the teachers' union and the government disseminated pessimism and demotivation within the school environment. Thus, other issues and demands prevailed during the interviews with individuals from School A than those related to datafication in education.

School B was built based on community demands and its construction followed protests and demonstrations due to the delayed delivery and low quality of materials. Its respondents share a more critical view about education policies compared to respondents from Schools A and C. For instance, School B respondents openly criticised policies and policymakers. Most 
of the School B staff had completed a higher education level when compared to the other schools. Specifically, the majority had completed Master's level degrees and some held doctorate degrees, a quite rare occurrence in Brazilian public schools. Different from School A, respondents in School B reported constant pressure to improve scores on LSAs and the school's position in IDEB.

The School C culture is based on solid values-respect, dialogue, commitment towards quality in education and teamwork - which, according to the respondents, were developed from a partnership with a Catholic church movement. This school obtained the IDEB top position within the state in a particular year. Respondents are proud to say that School C is well known as a 'good' school, having a 'high' IDEB. Thus, School C faces a high influx of both students and teachers willing to study and work there. Student and teacher selection is restrained by government regulations, except substitute teachers hired for fixedterm. Respondents expressed that such prestige offers additional challenges concerning quality in education, since they feel committed to maintaining the 'good' image of School C. I analysed school actors' discourses, following a discourse analysis approach (see Gee, 2011), to understand respondents' views on quality, evaluation, QAE policies and how they enact such policies. Discourses are not simply speeches; 'they are performative and produce particular versions of social reality to the exclusion of other possibilities, thereby substantially shaping socio-economic, institutional, and cultural conditions and processes' (Greckhamer \& Cilesiz, 2014:424). Thus, I view the discourses as part of a larger whole, reflected within the existing power relations, ideologies and practices (Foucault, 2005, 1989). Through school actors' discourses, I also aimed to identify the effects of data production and circulation in the school environments, actors' interactions and in respondents' attitudes, beliefs and practices. 
The conditions and timing of the interviews might have influenced the respondents' answers. SAEB was administered to students during the fieldwork period, and some schools were on strike when I was conducting this research. Given the data collection methodology, the findings are not representative of Brazil or the localities in which the research was undertaken. These findings, however, are relevant to understanding the effects of QAE policies in schools. When analysed comparatively, the perspectives of this analysis may reveal patterns that are arguably meaningful for the investigation of the effects of datafication in education in other contexts.

\section{Enactment of QAE policies in schools}

The intertwinement of quality, evaluation and data manifesting in QAE policies is rather complex. But how school actors enact them is even more complex. This section presents the ways in which QAE policies are enacted in School A, School B and School C. For the sake of clarity, I divide the findings into three sections: the first covers the school actors' discourses concerning what they see and understand with regards to QAE policies, dealing mostly with their imaginaries; the second part focuses on discourses about how school actors engage with such policies, taking into consideration their narratives concerning the implementation of QAE policies; and the third section concentrates on discourses about the effects produced by the enactment of QAE policies in school environments, school actors' conduct and their imaginaries.

As mentioned above, the main focus of the analysis of the enactment of QAE policies is on aspects related to datafication in education. In line with existing literature, this research regards both social interactions and individuals' subjectivities as relevant to capturing policy enactments. Due to the contingent nature of policy, different possibilities and realisations of QAE enactments manifest in these Brazilian schools, ranging from following the regulations 
to ignoring, proposing alternatives and resisting. The findings of this research are presented and discussed below.

\section{School actors' understandings of $Q A E$ policies}

The discourses across the 28 interviews with school actors shared a rather consistent view about quality and evaluation in the three selected schools. Quality is perceived as abstract and relative, as well as a powerful political discourse. Quality in education, in turn, represents a more generic goal towards the future - a target rather than a recurring practice. Despite constant efforts among school actors to deliver quality education, their discourses project an ideal of quality in education for the near future - that is, a 'would be' situation. This is reflected in phrases like the following: 'when students appropriate knowledge' (School B); 'commitment can develop quality' (School A); 'aspects we aim to achieve, targets' (School A); 'real education to children, teachers, families (...) but it is still lacking' (School C). Their responses provide normative discourses of what education should or should not be, encompassing different values and expectations about it (e.g., inclusion, dignity, freedom, autonomy, equality, equity, critical thinking, relevant skills for the future and citizenship), the means of attaining it (e.g., well-trained and committed teachers, good textbooks, wellequipped schools and solid pedagogical methods) and who should be responsible for providing the desired quality (e.g., government, school principals, teachers, parents and students). The latter varied depending on the position of the respondent; many discourses imply that the government is not taking its dues responsibilities for assuring quality in education seriously.

Nearly all school actors agree that quality must be evaluated, adopting a more rational and instrumental discourse than the ideological discourse about quality alone. In their view, without evaluations there is no way to ensure whether quality is achieved. A great number of 
school actors, representing different schools, declared that 'all types of assessments are welcome'. But the discourses express their own needs and motivations for evaluating quality, such as the need for orientation and for feedback, thus partially connected to selfimprovement, self-criticism, and self-regulation.

I have to measure quality in order to define what it is. (School A)

I think we must evaluate quality in education primarily to know which types of gaps we have and which aspects must be improved. (School B)

Quality must be evaluated, compared, to create new parameters, to see what can be improved. (School A)

Evaluation makes us grow, improve. (School C)

School actors clearly find it necessary to have some sort of data to assess quality and to orient them in future actions towards improving education. This confirms the alignment of their discourses with the current modes of governance in education in Santa Catarina, which depend on data and self-regulation (Candido, 2018).

Yet, school actors' discourses diverged concerning QAE policies across institutions as well as within schools. Some respondents-primarily school principals, coordinators and supervisors - were more familiar with QAE policies, while other participants were only concerned with aspects of QAE relating to themselves, individually and as a group (e.g., institution). Students were the most indifferent to QAE policies.

The discourses of few respondents, primarily from School A and School C, but also from School B, support the current QAE policies. Such discourses praise the existence of different instruments (i.e., SAEB, IDEB and Prova Brasil) to provide data for self-evaluation, to ensure student learning and to improve the quality of the school (in a somewhat linear perspective). 
We need them [LSAs]. I am not sure they are the ideal model [of assessment], whether they should be done the way they are done now, but they provide feedback to teachers. When you see a student doing the test (e.g., Prova Brasil), you can visualise that you are, sometimes, a little bit outdated concerning the types of questions, the contents that are assessed. I find it very important to have them to measure [quality in education]. It is a challenge, but not in a negative way. (School A)

[QAE policies] offer support to teachers instead of increasing their workload. When they want to prepare students for an assessment [LSA], the contents are already available to them. (...) Teachers have the chance to improve themselves, to feel more confident about which content should be taught. (School C)

Evaluations and indicators are important to maintain the [quality] level. Let's assume that education [in School A] is 5. The assessment [LSA] will show what is wrong, we will aim for grade 6 next time. If we get the 6, we cannot let it drop to 5. Evaluations are important to raise the [quality] level [of the school]. (School A)

Most of the respondents, however, criticised the QAE policies. That criticism prevailed in School B, but also appeared in the other schools' discourses. For instance, some school actors reported that the 'external' character of the assessments renders them decontextualised with regards to the school characteristics, issues and demands, and concerning the background of the actors involved in those assessments.

I don't buy [LSAs] because they are all uniform. They are not designed for [School B], which has a specific way of working, they were not made for another school which works in another way, nor for a third school which follows a very traditional means of evaluating students. (...) Each school is completely different from another. (School B) Education cannot be measured only by assessing the student. Education should be measured in relation to the context: the level of education in Brazil, the result in a particular test, the school conditions, the teachers' life conditions. If we aim to 
understand the context of the students, we also need to understand the context of the teachers. (School A)

School actors' discourses also express concerns regarding the lack of potential within QAE policies to improve quality in education. One respondent from School B argued that LSAs aim 'to rank schools, to make schools responsible for the issues they have, and not to effectively qualify education'. This excerpt illustrates both the instrumental nature of QAE and the expectation to qualify education created through data. In essence, this response mirrors the critical discourse among Brazilian scholars, reflecting the blurred boundaries between the goal of quality in education and the means of achieving it (Candido \& Lappalainen, submitted). School actors pondered that the current QAE policies focus on the ends rather than on the entire learning process, thereby empowering some actors (i.e., government representatives) when scores and indexes are positive and blaming others (i.e., teachers) when the outcomes are worse than expected. According to the interviews, QAE does not necessarily produce quality, but rather controls education.

The government gives all responsibility to the teacher: if some class performs low it is because the teacher was not able to handle the situation. (School B)

Interestingly, actors from each of the three schools provided a dichotomous discourse about the contents of the data gathered through QAE policies, raising positive and negative aspects of the contents. Some argued that the tests are based on contents and methods that are more suitable for the skills required in the near future, such as this example: '[LSAs] are welldesigned because they make students think out of the box, preparing them for life' (School C).

The dichotomous discourse, nevertheless, ultimately highlighted the negative aspects of QAE policies. Most school actors shared the opinion that QAE policies simplify what is 
taught and learned at school, leaving students unprepared for their future lives, since the test and programme contents are narrower than the core curriculum. In their view, this is particularly problematic due to the explicit (through government deliberation) and implicit (based on public opinion and on the stakes of the $\mathrm{LSA}^{9}$ ) over-emphasis on out-performing. [PNAIC, a federal programme for ensuring that 8-year-olds know how to read and write] is a reduction, not the totality of the situation, they [government] organise trainings and limit teachers['s autonomy] (...) These [the PNAIC textbooks] are very superficial (...) they do not prioritise the knowledge (...) The teacher should work with those textbooks during a certain period to be able to administer the test, because its contents are the same as the contents of the textbooks, so the teacher trains the students, a mechanical training. (School B)

This excerpt illustrates the discourse of other respondents as well as the concern for other QAE programmes and instruments. On the one hand, school actors regarded QAE policies as well-constructed mechanisms articulated through teacher training and curriculum. On the other hand, their discourse reveals that QAE policies produce side effects, such as limited teacher autonomy, less time to cover all of the contents and the standardisation of individual learning paths. As a consequence, QAE policies (and their contents) become more important than the curriculum itself, and teachers, according to the most critical respondents, become more vulnerable to government interests. Moreover, school actors argued that these side effects affect other policies, such as funding, teacher training and career development.

\footnotetext{
${ }^{9}$ Some states and municipalities in Brazil adopt performance-based schemes to reward high-performing IDEB of schools. But, the LSAs remain low-stake in Santa Catarina, where a high IDEB performance grants the school symbolic power alone, manifesting in school status and prestige (Gurova et al., 2018).
} 
Notably, both types of discourses - that of praise and that which critiques - use 'scientific rationality', from pedagogical to economic theories, to sustain their arguments. Furthermore, all discourses convey the expansion of the scope of QAE policies, including students' and teachers' self-evaluations, teachers' external evaluations, schools' internal assessment mechanisms, and the assessment of government concerning education provision.

Teachers should be versatile, they should be prepared to receive critiques, to understand that criticism improves their work, and consequently, students' learning. (School A)

For a total improvement, we need to evaluate all professionals in education, including school management, because it [evaluation] produces growth, and breaks the monotony of doing things the way they have always been done. (School C) The quality of the government in allowing schools to develop their roles should be assessed. (School B)

School actors suggested that assessments should be not only objective and quantitative, but should also employ subjective and qualitative approaches. In addition, their discourses convey that LSAs should include other dimensions of education and of the social space, as illustrated in this excerpt: 'a test is something too restrictive, too isolated; thus, we have to measure other things that happen in the school and that exist in reality' (School A). This extract implies that numbers may represent things that do not exist. Such an inclination towards assessments and evaluations shared among the respondents indicates that school actors find data crucial to governing education and orienting the teaching and learning processes. This corroborates the penetration of datafication in the imaginaries of school actors in Santa Catarina. 


\section{School actors' engagement with QAE policies}

As expected from their bi-polar standpoint concerning QAE policies, school actors' discourses offered different perspectives about their engagement with those policies. In general, their discourses convey that policies only become meaningful when connected to problems individuals aim to solve. The discourses praising QAE policies, primarily from School C, but also amongst actors from School A and School B, emphasise the role of data (particularly, assessments and indicators) as the guiding instruments for planning and for orienting teaching and learning. Interestingly, not only are the results taken into consideration, but also the contents of the tests.

When the test [Prova Brasil] comes, we see the contents that have been requested [for students], the questions, and we reflect on whether we have worked on those contents, followed the reasoning [of the test], whether our planning is associated with the reality of our state, of our country (...) We, thus, have an understanding and are able to make improvements in the following years, in classes that will be evaluated [in the upcoming years] (...) We have some guidelines. (School C)

I have started to prepare materials for working with students [who will be assessed in Prova Brasil in the following year]. I made a test for them and the results were bad. So, I began preparing them for the Prova Brasil that will be administered next year.

(School C)

A group of school actors, predominantly from School A and mostly in administrative positions, embraced the possibilities stemming from the comparability enabled by QAE policies. They reported that when the LSA results are published, they immediately compare their schools with others, and with the general results at the municipal, state and national levels. Their discourses indicated that comparison is relevant in order to confirm whether a school is 'delivering' what is expected, to ensure the school is following the standards of 
education and to set goals for improving its actions. In one way or another, comparisons, according to respondents' discourses, centre on quality in education.

Indexes are important to me (...) When I look at IDEB, the first thing that I do is compare my school with another (...) This is natural. To my understanding, indexes, numbers, they say something (...) whether the school is good, whether it is not, whether our work was good (...) I believe that we have to use the indexes to improve. (School

A)

Data has been instrumentally used in both cases, first, as a tool for planning and for orienting the teaching and learning processes, and, second, as a comparability mechanism. The instrumental use of data in the first case associates with actions oriented towards the future. The school expects to be more efficient, that is, to attain better scores in LSAs in subsequent years. Therefore, discourses emphasising concrete actions-planning, as well as changes in how and what to teach—provide solutions and alternatives for a self-declared failure in the present. The second case consists of school actors who enact QAE policies to assess their work in comparison to others - that is, 'comparability as a mode of governance' (Nóvoa \& Yariv-Mashal, 2003:426). Once they have data, comparison is natural and automatic, according to the respondents. But, overall, such discourses refer to comparisons from a decontextualised perspective, relying mostly on numbers. In both cases, school actors appear to self-regulate their collective and individual actions, delimiting their own conduct and setting standards of 'good' and 'bad', 'correct' and 'incorrect' outcomes.

Yet, the improvements the respondents aim (or expect) to achieve in education through the use of data remain unclear, since their assumptions and strategies cannot be confirmed before the disclosure of the next round of LSA results. Such uncertainty aligns with the construction of abstract entities enabled by data. Those school actors seemed to reinforce a script that emphasises that the 'good' use of data leads to positive 
accomplishments, whereas the positive outcome is 'good' data (e.g., a high IDEB). Thus, they navigate in a world in which data serve as both the departure point and the final destination. There is little room to define the desired improvement from a non-quantitative perspective and to reflect upon how data along with other factors contribute to such an improvement. This indicates a transformation in the purpose of school. The blurred connection between the means and ends, problems and solutions, goals and outcomes as well as instruments and results agrees with the claim that QAE 'rather than quality itself has become the objective of education' (Kauko et al., 2018:181).

Other discourses, however, remain critical or even pessimistic about school actors' concrete engagements with QAE policies. Such discourses were easily identified among School B's actors, although present in all three schools. This criticism covers a variety of standpoints. Some respondents adopted a more tangible perspective, claiming that the lack of resources and the non-alignment of QAE policies with the demands of the school community represent obstacles to their engagement with those policies.

Yes, it is a comprehensive policy, but it requires funding. It is no use having a policy without funding. (...) I cannot see new policies [coming] to this school without having [the proper] infrastructure. (School A)

Other discourses criticise the objectives and purposes of QAE policies, as well as the processes of data production and circulation, to justify school actors' poor engagement with such policies.

There is a lack of transparency of the external assessments' objectives (...) there is no intention to make the whole process more transparent (...) The government does not prepare teachers to participate in the external assessment (...) nor the students. (School B) 
Sometimes I ask myself why, for what purpose, by whom, for whom they [QAE policies] are interesting, and what we are expected to achieve with them. (School C) We are oblivious about Prova Brasil. I am not sure whether the test is difficult or whether the quality of education [in general] is bad. (School A)

The low degree of engagement with QAE policies, manifested in these critical discourses, associates with problems emerging outside the school jurisdiction, under the responsibility of the government. According to the respondents, most QAE policies are unilaterally developed and flow from the government to the school in a top-down direction. The following discourse from a school actor from School A illustrates this: 'the [large-scale] assessments are topdown and the problems are here, at the bottom, concerning the students' development [in education]'. This is particularly perceived in policies defined by the national government, but also covers QAE policies originating at the state and municipal levels. Whenever schools have an opportunity to participate in policymaking, through the delegation of a school representative to attend governmental meetings and trainings, through the communication of school demands via formal channels (e.g., documents) or through processes related to collectively revising documents at the school level, respondents stated that they do not feel as though their ideas were truly embraced by government bodies. At the municipal level, however, due to the lower complexity and higher proximity of actors, participation in policymaking is enhanced through dialogue. Yet, a hierarchical relationship persists. Students reported often feeling left out of discussions.

Creating possibilities for different sectors of society to participate in policymaking is a feature of the current mode of governance (Candido, 2018). However, respondents' reluctance to view their ideas as accepted shows inefficacy of school actors' engagement in policymaking. This relates to governance at a distance (Miller \& Rose, 1990), which 
emphasises self-regulation and manifests through the indirect intervention of the state through QAE policies as 'technologies of government'.

Governance at a distance is also apparent in the limited flow of communication between the government and schools, a reality mentioned in school actors' discourses. Living in a paternalist society, respondents expected to be well-informed about QAE policies. But, in practice, they fail to receive information. New policies and changes to existing policies are communicated primarily via online channels (internet and intranet). Occasionally, school principals attend meetings organised by the government during which policies receive brief mention. Meetings occur more often at the municipal level, whereas the state government uses online seminars and trainings to disseminate QAE policies. Respondents expressed their disappointment with prevailing communications with the government, since no possibility exists to clarify school actors' doubts and questions in a customised or personalised way. Thus, school actors feel excluded from the QAE processes.

When students do not feel they belong to the process, they will not create an identity with the school; when teachers and schools do not participate in the discussion process of external assessments, they won't feel they belong to it. (School B)

In addition, changes are not communicated well in advance. Instead, they come as a surprise. 'They come in parachutes', as one respondent from School C pointed out, yet demand very quick reactions.

The national LSAs are administered every two years, but it takes time- ' around a year', according to the respondents, to disclose the results. By the time the results arrive, some students - particularly those who completed the test in the ninth grade — no longer attend the same school, and 'teachers are doing something else, they have other issues on their minds, they are working with other things, and do not remember them [LSAs]' (School C). But, more importantly, communication about the SAEB and IDEB results remains poor, 
according to the school actors' discourses, since they rely on numbers alone, without any kind of feedback, which school actors greatly anticipated.

I do not see any feedback; they administer the test, take it away from us, and that's it, there is no feedback' (School A)

We receive very little back, we read the results in the newspapers, we listen to them on the TV (...) We do not receive the feedback that I think we should receive (...) We are still far from what could really make a positive impact towards the improvement of education. (School C)

The slowness, the lack of communication, the lack of feedback, and the lack of training coexist. (School C)

This undermines school actors' impressions about QAE policies, fomenting uncertainty instead of any objectivity and certainty supposedly enabled through data. The lack of information from and involvement with policies results in a lack of commitment among school actors towards QAE policies, as expressed by a respondent from School A: 'the largescale assessments come from outside; Prova Brasil is not discussed beforehand, creating resistance among teachers'. Such an unclear process ultimately impacts the core of QAE policies from the government's perspective, that is, its outcomes: 'if students are not prepared and teachers are not prepared, the test results will be bad' (School B).

\section{The effects of QAE policies enactments in schools}

School actors not only reported changes in the school environment and work routines resulting from the enactment of QAE policies, but also mentioned shifts in school actors' conduct and attitudes. The primary motivation behind changing, according to their discourses, stemmed from the perceived benefits of QAE policies of improving quality in 
education. Thus, QAE policies were integrated into the daily routines at schools through the adoption of new teaching and evaluation methods, primarily in School B and School C, and through the organization of school events (e.g., meetings and trainings) to discuss QAE policies in all the three schools. For instance, one respondent recounted that all teachers involved in a particular LSA in School B suddenly started to 'talk all the time about competencies and skills' using the 'language' of the policy documents. Other respondents described how teachers in School C incorporated questions from SAEB into regular school exams and organised preparatory lessons and tests with students prior to the administration day for LSAs. These two examples illustrate how school actors' suit their discourses and conduct to QAE policies despite the lack of coercion, threats or incentives to stimulate such alignments. Thus, shifts in conduct, discourses and attitudes are voluntary, although not always conscious. Overall, changes amongst teachers appear to rely on self-regulation and the ‘intelligent accountability’ described by Ozga (2009), being more dogmatic than reflective.

In other situations, however, engagement with QAE policies contributed to a discontinuation of school actors' prior conduct, as illustrated in this episode described by a school actor from School B:

A new teacher started working at School B. The new teacher organised her classroom in a very creative way, using pictures on the walls to emphasise the contents of the subject. Some days later, two senior teachers entered the classroom and told the new colleague that the way she had organised the classroom was not in accordance with QAE policy instructions. The two more-experienced teachers recommended that the new teacher change the classroom. The respondent, who was in the classroom when the senior teachers arrived, comforted the new teacher and suggested keeping the classroom the way she preferred it. The newcomer soon started to participate in trainings about that QAE policy and her classroom has never been the same; it looks like any other classroom of teachers who participate in the QAE policy training. 
The new teacher described in that episode initially built parallel structures to combine her preferences with the demands of QAE policies. Later, her colleagues pointed out the inconsistencies between the organisation of her classroom and QAE policies. The newcomer, perhaps seeking to belong to the group, influenced by others or seduced by QAE policies, adopted a self-regulating attitude and changed the classroom, assimilating the policies.

LSAs have become increasingly natural in all three schools according to school actors' discourses. They also point out the development of a school culture that embraces and normalises performance evaluation, comparability and continuous improvement, showing some degree of accommodation with QAE policies in the schools.

I find them [LSAs] interesting because we are assessed in life, we are assessed about everything we do. Thus, I also think that students should be [assessed]... (...) I talk to students, encouraging them [to take part in the LSAs], explaining that in the future they will be assessed when they apply for a job... (...) [LSAs] are very good for us, teachers, to evaluate our work, to see how well our students are doing. (School B) There is Prova Brasil, then, there are the [other] tests, exams... [Previously] there were high expectations [about the tests]. Now we consider them a natural process. (School C)

Comparing is natural for me. Indexes, numbers, they have a say. (School A)

In addition to self-regulation, school actors' discourses refer to self-evaluation and selfimprovement, which became an inherent feature of school practices.

I find them [LSAs and indicators] interesting, because you get an idea of how you have been assessed (...) you have a guideline to follow and then you know your position in the whole context (...) We can compare and also self-evaluate ourselves... whether we are following the guideline, what is missing, what we need, what we should change. (School C)

When I evaluate a student, I also evaluate the quality of my work as a professional. (School A) 
It is possible to improve the negative scores [in LSAs], isn't it? I believe so. (School B)

QAE policies were adapted to some school actors' previous ways of doing things. Beyond the actors' attitudes, concrete measures were undertaken, such as the integration of LSAs in the annual school schedule, the use of data as evidence for planning and the submission of reports to the government. A school actor from School A, for instance, mentioned that he uses different indicators in the meetings he organises to highlight the need for improvements. School actors described how QAE policies are assimilated into School C:

We should input it [how the QAE policy is implemented] in the report (...) Everyone works (...) inside the classroom in the best possible way to connect it [the QAE policy] to the content [of the subject], to add it to the schedule. (School C)

We take the students to the computer lab where the tests are ready for them. And what do they do? A preparatory test. Why? What do we want from this? We want them to learn to read and interpret [the questions on the test] (...) to avoid the feeling they had in the first editions of Prova Brasil. We perceived that they were anxious and even their hands were sweating. (...) They created a high expectation, so now we intend to transmit it as a natural process. (School C)

In contrast to assimilating and accommodating QAE policies, other discourses among the school actors refer to resistance towards such policies. Some respondents recounted their refusal to participate in LSAs in the past. Other actors described situations in which the school administration and the teachers' union organised demonstrations against QAE policies. Such discourses refer to the lack of involvement of school actors in policymaking and the lack of political commitment from the government towards quality in education as the primary reasons for their non-compliance with QAE policies. One respondent from School C, for instance, argued that QAE policies 'are not designed towards quality, but towards 
quantity', and 'politics is more crucial than quality in education'. This discourse conveys that policymakers regard 'good' numbers as more important than quality in education, since good scores grant political recognition in a global context that values data. This idea was supported by other school actors, as expressed here:

Government officials are not concerned about what happens in the classrooms (...) I have never seen any government official asking whether the work of a certain teacher ensures students' learning, I have never seen that (...) The only way the government attempts to do this is through external assessments (...) I see that quality means numbers to the government. That's what they are worried about. (School B) To the government, quality in education is to keep students inside the classroom, at any price; it is irrelevant what teachers do inside the classrooms. (School B)

School actors, however, cannot renounce QAE policies due to their limited political power. Instead, they propose alternative modes of 'counter-conduct' (Foucault, 2007). Actors at School B, for instance, debated about and reflected upon QAE policies at school meetings. These discussions were synthesised in a document sent to the government. One respondent stated that it was impossible to 'avoid the participation [of School B] in the large-scale assessment', so the teachers of School B decided they would not administer the test as a form of protest against QAE policies. In the face of such resistance, the government sent representatives to administer the test.

Resistance represents an extreme way of enacting QAE policies. Another possibility for enactment that differs from government expectations is manifested through the rejection of QAE policies. Despite participating in the LSAs, one school actor from School B, for instance, stated that 'the results of the large-scale assessment will not be taken into consideration in teaching practices.' Rejecting LSA results, indicators and regulations could also indicate decoupled or symbolic responses to QAE policies. That is, a set of discourses 
imply that school actors have some sort of the power to act as they wish, regardless of the regulations, as expressed by a school actor from School A: 'the classroom is closed; the teacher closes the door and does whatever s/he likes.' Thus, there is room for action within schools to enact policies, as reported in School C: 'it [the policy] comes as a regulation, but the school decides how to work on it.'

Decoupling also manifested when school actors talked about QAE policies with indifference, when these policies are not prioritised among their activities. Indifference towards QAE policies was quite common in the discourses of teachers who participated in a strike for better salaries and working conditions that took place during my fieldwork, as well as among students. While most of the students interviewed for this study thought that the tests were easy, they reported disliking doing LSAs, since the time could be used for other things, such as a school lesson.

[LSA] tests do not assess quality [in education] because they come from other places [not from the school]. Everybody answers the tests in a playful way [joking about the tests] because they are not graded. They are not taken seriously. (School B)

In such cases, school actors seemed to show more complacence regarding QAE policies than commitment. Some respondents mentioned that they write reports, participate in training, administer the LSAs and take tests without engaging with QAE policies, because they have other priorities and do not feel compelled to commit. These discourses are closely related to what Maguire et al. (2015:496) described as 'interpreting policy to fit their own agenda'. Those school actors do not complain or refuse the policies, but enact policies without incorporating them. They seem to do whatever is needed in order to comply with the QAE policy to move beyond it as soon as possible in order to focus on what is more important to and for them. As such, school actors' discourses may lead in two different directions concerning the decoupling of QAE policies. First, school actors have different interests, 
whereby QAE policies are not necessarily among their priorities. For instance, they are so enthusiastic about teaching that they are blind to anything other than their passion for education; they are going through a challenging stage of their lives or careers (e.g., transitioning from childhood to adulthood in the case of students; balancing between private and professional lives in the case of other school actors). Second, school actors are selfconscious about the 'technologies of government' manifested through QAE policies. In this case, they pretend to follow the QAE 'game', thereby avoiding any consequences associated with rebelling against such policies. But, in fact, they seem to find ways to rewrite the rules of the 'game' to fit their own interests and enact the QAE policies in disguise within the prevailing performative society. This serves as their form of 'care of the self' (Ball, 2016). In another situation in which school actors' discourses express decoupling with regards to QAE policies in a more 'fearless speech' style (Ball, 2016), they suffered the consequences of pondering their values and opinions when enacting QAE policies.

I will tell you about something that happened at our school at the end of the year. We held teachers' board meetings for every class and around 30 students were retained due to a high absenteeism from lessons (they had not maintained the minimum of $75 \%$ of attendance [during the entire school year]). On the last day of school when we were celebrating the year-end closing with teachers and other school staff, we were surprised by the arrival of a group of three or four representatives from the government. They requested a meeting with the school management team to understand the retention of those 30 students. They asked for proof that we had followed all of the required procedures: contacted the families, followed the drop-out action plan defined by the public prosecutors, contacted the local guardianship council [which is responsible for providing social assistance to children when the family does not provide it] (...) We stayed late at school after the end of the celebration to gather the information required by the government representatives. I went to the Secretariat of Education to take the 
documentation (200-300 pages of documents) to prove [that the decision to retain the students was correct]. I was harassed [by the government] to amend the decision of the teachers' board meetings. (...) I was harassed under allegation that the retention of those students would reduce the index of the school, the IDEB. (...) It was an intimidating speech: 'this will reduce the school's IDEB; if the school has any ongoing projects [funded by governmental programmes] and you are retaining students, the IDEB will drop and we [government] will end all projects at the school, we will close the labs'... (School B)

In the end, School B refused to change the decision regarding the retention of those students. Such a confrontation was supported by documents proving that the school actions adhered to the education regulations. Another school actor, who also described this episode, stated that none of the existing projects continued in the following school year, and the school did not receive any incentives (financial support, recommendation or encouragement) to develop new projects.

Despite the low stakes of LSAs and indicators, non-compliance with QAE policies in Santa Catarina could be risky to schools. The school staff in the three schools featured in this study, already working under precarious conditions when compared to other professionals in Brazil and to education professionals in other countries, reported anxiety and fear of punishment from the government. Punishment is illegal, although threats are lobbed regularly to ensure no one deviates from the disciplined conduct aligned with the modes of governance in the state, which clearly value data more than the education process. 


\section{Concluding remarks}

Brazil has been creating a data infrastructure in education for decades. Expanding the scope of evaluation and introducing new instruments ${ }^{10}$ have complemented the dissemination of a culture of data penetrating schools, as demonstrated in this study. In addition to implementing QAE policies, school actors — even those most sceptical— have incorporated datafication into their discourses, imaginaries, and conduct, according to the analysis. Ultimately, they understand education through the lens of data and engage in education incorporating the idea of governmentality through data.

Here, I analysed QAE policies as means of datafication, since such policies rely on data-infrastructures, producing and being legitimised by data. As expected, school actors do not share a homogeneous understanding of QAE policies. Rather, their discourses range along a continuum from appraisal to criticism. Similarly, school actors' engagements with QAE policies were also distinct; some actors engaged more than others, coupling with or decoupling from policies. In general, however, school actors reported that communication problems with government limits the possibilities for engagement. The enactment of QAE policies resulted in changes in schools' routines and in school actors' conduct, independent of whether they assimilated, accommodated, rejected or refused QAE policies. Even the types of enactment seemingly less emphatic towards QAE policies concealed possibilities of seeing, understanding and engaging with the world through data, according to school actors' discourses, since respondents remained critical of specific QAE policies rather than of data per se. It seems inconceivable to talk about quality in education in schools without referring to measurement, evaluation and data. This research showed that data is part of the daily activities in schools and have transformed the functions and purposes of education.

\footnotetext{
${ }^{10}$ For instance, in 2019, a LSA for early-childhood education will be added to SAEB (INEP, n.d.).
} 
Such transformations enabled by data through the enactment of QAE policies in Brazilian schools resemble the five consequences of datafication Jarke and Breiter (2019) found across different educational settings. First, datafication revealed new spatio-temporal entanglements in the three researched schools. The emphasis on virtual environments and virtual communication, as reported in school actors' discourses in this research, features a double character. It creates proximity through real-time and quick ways of delivering messages, reports and documents while simultaneously depersonalising interactions, rendering them more distant, less humane and more mechanical.

The comparison of education in those three schools with other entities (different schools, municipalities, states and countries) seems to loosen borders, enable benchmarking and empower people at the expense of reliability and rigor, since some entities are not necessarily comparable and comparisons tend to be decontextualised. According to the school actors' discourses, LSA scores, indicators and rankings are decontextualised at the local level in Brazil. They appear to function as evidence for quick decisions, following a managerial logic, in which efficiency is measured based on the shortest time necessary to solve problems and explanations about the context would be too time-consuming.

Nevertheless, the acceptance — or rejection—of datafication remained context-specific in this analysis, aligned to Williamson's (2017) research. The three schools' socio-historic context appeared relevant to actors' enactment of QAE policies. For instance, the discourses of school actors from the school with a more critical culture were generally more sceptical than those from the other schools; and the discourses from School C, the school that achieved the top position in the state IDEB ranking in the past, were more oriented towards maintaining its good results and constantly improving.

Furthermore, datafication in education proposes a new temporal horizon for schools. Specifically, their activities function around LSAs, based on a cycle beginning at least one 
year earlier, when students are prepared for the subsequent year's tests, following the LSAs administration, and ending with the publication of LSAs' results. The results, then, are used to plan, discuss and set new targets concerning the school cycle. While people change along this cycle — some students and school staff are no longer at a school when results are disclosed-LSAs receives more space in schools (e.g., when defining the contents to be taught and the methods for the regular assessment of each subject).

Second, datafication allows for new forms of participation in the education process. Brazil's latest education plans call for the involvement of communities surrounding schools and other sectors of society in education (Candido, 2018). An implicit intention exists to politicise society and, specifically, to politicise and privatise education, not necessarily through the incorporation of public education institutions in the private sector, but primarily by opening up discursive possibilities to accommodate different individual and collective (e.g., corporate) interests within public education. The analysis of QAE policy enactments presented in this article identified the emphasis placed on a results-oriented approach to govern education at the school level. In addition, importance was placed on transparency (both at school and at the government levels) enabling school management and empowering individuals through not only outcomes, but also best-practices (and 'worst-practices', when applicable) and choices. Therefore, school activities, which historically remained within school walls, have become widely distributed through the 'datascape' (Jarke \& Breiter, 2019:3), without controlling who accesses and uses such data.

Third, datafication enabled through QAE policy enactments creates new possibilities for actors to engage through data, depending upon their competencies and motivation to interpret and use data. In addition, these new possibilities also depend upon the relationships they built in the school environment to support their position concerning data in education and the changes they aim to achieve in order to accommodate, assimilate to or resist 
datafication. Such interactions among school actors and QAE policies result in divisions, such as the situation involving the new teacher who creatively organised her classroom and those teachers who disapproved of the newcomer's conduct, described by a respondent from School B. Divisions generate uncertainties and increase inequalities in the school environment, increasing discomfort, stress and competitiveness among school actors.

Fourth, datafication leads to new conceptualisations of agency and the redistribution of agency across socio-technical networks, compounded by human and non-human actors. The role of algorithms (e.g., IDEB scores) in allocating schools' funding, teachers' salaries, and children in classrooms (via performance-based schemes) has expanded in Brazil. Yet, these developments are in their initial stages in Santa Catarina, although this does not mean they remain undiscussed. Engagements with data among school actors from the three researched schools indicates an intention to use data more often in the near future, which will expand the agency of data as well as the construction of socio-technical networks based on school demands. The increased agency of data, however, may lead to individualistic and mechanical conducts, as illustrated in the discourses of school actors in Santa Catarina. That is, the perceived objectivity of data serves to promote personal interests and standardized protocols.

Fifth, although not least important, datafication in education allows for new forms of control, monitoring and surveillance of schools. The government utilises such features to steer the work of schools and school actors, and to ensure that they are sufficiently disciplined to produce the expected outcomes. Data, however, represents a 'technology of government' beyond the state level. Monitoring and surveillance mechanisms are also employed by school actors to ensure that the functioning of the schools remain under control. This control relates to the increasing managerial functions allocated to school actors, associated to the number of students per class and of school staff to supply schools' activities, 
the pedagogical and additional resources required to continue work, maintaining the infrastructure and, in some cases as demonstrated in School A and in School C primarily, in terms of students' and teachers' performance. Governance in education relies on continuous monitoring by different actors (through the involvement and participation of larger groups of people and interests), enabled through transparency, accountability and comparability. School actors have been charged with and pressured to comply with this logic. Thus, some school actors, primarily principals, who govern education at the school level, become controllers inside the educational institution. (Parents, at times, also assume this role, aiming to maximise education results provided for their children.) In such context, data become imperative at schools, as shown in the analysis above. Besides using data to govern education and govern schools, school actors also use data to govern their own conduct as professionals and educators in a self-regulated manner.

This analysis of QAE policy enactments demonstrated that school actors' discourses weaved interconnections between datafication in education and at school (e.g., evaluations) with other types of datafication in one's life. These connections assume that schools (should) reproduce the same values and principles prevailing in other social fields. Essentially, this resembles a cascading effect of 'datafication' from the political and economic systems to the educational space. It becomes possible because school actors, including the most critical respondents, incorporated the self-regulation embedded in governmentality. Terms such as 'self', 'improvement' and 'comparison' quite frequently entered into school actors' discourses. Moreover, some of their QAE policy enactments demonstrated disciplined conduct and attitudes, and their discourses indicated that data is both naturalised and institutionalised in schools.

Despite the limited possibilities for action, constrained by regulations and power relations, policies remain contingent, as reflected in school actors' enactments of QAE 
policies. In some situations, school actors found themselves more empowered to make decisions, adjustments and adaptations, to raise their voices and to propose alternatives. In other circumstances, the lack of power and resources limited any room for manoeuvring. Yet, according to the respondents, there are spaces within schools where policies do not reach. Furthermore, some school actors appear more reflective than others about QAE policies, seeking to understand what these policies actually propose and offer beyond the official discourses. Thus, they tend to manifest a 'counter-conduct' instead of incorporating policies without questioning them.

To conclude, this article aims to shift attention away from what is actually measured when identifying QAE policy enactments within schools in order to offer some clues regarding how datafication penetrates into schools. In addition to the remarks listed above, this analysis allows us to understand the contributions of datafication to politicising or depoliticising issues in education. While politicisation transforms something as political, as 'playable' (Palonen, 2003:171), depoliticisation exhausts or reduces interest in politicking through the naturalisation or institutionalisation of ideas (Erkkilä \& Piironen, 2009). This analysis of Brazilian school actors' discourses indicates a constant conflict between the politicisation and depoliticisation of certain ideas, such as quality in education, which becomes depoliticised alongside the emergence of a culture of data. Evaluation, indicators and data gain relevance in different discourses, whereas quality assumes a marginal position. The enactments of QAE policies embedded in resistance, however, present a 'counterconduct', placing the effects of datafication at the fore through politicisation.

Policy borrowing and lending theory suggests that new policies can either add to or replace existing practices and policies (Steiner-Khamsi, 2012). This study shows that policies can be rejected, renounced or ignored, and that decoupling or proposing alternatives often takes place rather than simply adding new policies to those that already exist or replacing 
them altogether. Such findings provide valuable contributions to Comparative Education and Education Politics research fields, which benefit from the micro-level analysis performed in this investigation when analysing QAE policies and datafication in education. Furthermore, this study reflects upon the dynamics of datafication from a Southern perspective, presenting endogenous ways of exploring global trends and discourses in education politics.

\section{References}

Anderson-Levitt, K. (2012) Complicating the concept of culture. Comparative Education, 48(4), 441-454.

Ball, S. J. (2016) Subjectivity as a site of struggle: refusing neoliberalism? British Journal of Sociology of Education, 37(8), 1129-1146.

Ball, S. J.; Maguire, M.; Braun, A.; Hoskins, K.; Perryman, J. (2012) How schools do policy: policy enactments in secondary schools. New York; London: Routledge.

Bauman, Z. (1992) Intimations of Postmodernity. New York; London: Routledge.

Besson, J. L. (1995) A ilusão das estatísticas. São Paulo: Ed. Unesp.

Braun, A.; Ball, S. J.; Maguire, M.; Hoskins, K. (2011) Taking context seriously: towards explaining policy enactments in the secondary school. Discourse: Studies in the Cultural Politics of Education, 32(4), 585-596.

Braun, A.; Maguire, M.; Ball, S. J. (2010) Policy enactments in the UK secondary school: examining policy, practice and school positioning. Journal of Education Policy, 25(4), 547-560. 
Candido, H. H. D. (2018) Public-Private Interface in Brazilian Education Governance: Reflections from a Subnational Analysis. Education Policy Analysis Archives, 26(131). http://dx.doi.org/10.14507/epaa.26.3604.

Candido, H. H. D.; Lappalainen, S. (submitted) Quality assurance and evaluation in Brazilian education: analysis of the national academic debate in the face of local and global developments.

Carnoy, M.; Khavenson, T.; Fonseca, I.; Costa, L.; Marotta, L. (2015) A educação brasileira está melhorando? Evidências do PISA e do SAEB. Cadernos de Pesquisa, 45(157), 450-485.

Centeno, V. G., Kauko, J., Candido, H. H. D. (2018) Quality Assurance and Evaluation through Brazilian lenses: an exploration into the validity of umbrella concepts. Comparative Education, 54(2), 132-158.

Coburn, C. E. (2004) Beyond Decoupling: Rethinking the Relationship Between the Institutional Environment and the Classroom. Sociology of Education, 77, 211-244.

Desrosières, A. (1998) The politics of large numbers: A history of statistical reasoning. Cambridge, MA: Harvard University Press.

Erkkilä, T.; Piironen, O. (2009) Politics and Numbers: The Iron Cage of Governance Indices. In: Cox III, R. W. Ethics and Integrity in Public Administration: Concepts and Cases. Armonk, NY: M. E. Sharpe, 125-145.

Foucault, M. (1989) The Archaeology of Knowledge. London: Routledge.

Foucault, M. (1991) Governmentality. In: Burchell, G.; Gordon, C.; Miller, P. (eds.) The Foucault Effect: studies in governmentality. Chicago: University of Chicago Press, 87-104.

Foucault, M. (2005) The hermeneutics of the subject. Basingstoke: Palgrave MacMillan. 
Foucault, M. (2007) Security, Territory, Population: Lectures at the Collège de France, 19771978. Basingstoke: Palgrave Macmillan.

Gatti, B. A. (2004) Estudos quantitativos em educação. Educação e Pesquisa, 30(1), 11-30.

Gee, J. P. (2011). An introduction to discourse analysis: theory and method (3. ed.). New York and London: Routledge.

Greckhamer, T.; Cilesiz, S. (2014) Rigor, Transparency, Evidence, and Representation in Discourse Analysis: Challenges and Recommendations. International Journal of Qualitative Methods, 13 (1), 422-443.

Grek, S. (2009) Governing by Numbers: The PISA 'Effect' in Europe. Journal of Education Policy 24(1), 23-37.

Gurova, G.; Candido, H. H. D.; Zhou, X. (2018) Effects of Quality Assurance and Evaluation on the Schools' Room of Action. In: Kauko, J.; Takala, T.; Rinne, R. (Eds.) Politics of Quality in Education: A Comparative Study on Brazil, China, and Russia. London: Routledge, 137-160.

Hardy, I. (2015) 'I'm just a numbers person': the complexity, nature and effects of the quantification of education. International Studies in Sociology of Education, 25(1), 20-37.

INEP (2018) Nenhum estado atinge a meta do Ideb 2017 no ensino médio. Notícias. Available at: http://portal.inep.gov.br/artigo/lasset_publisher/B4AQV9zFY7Bv/content/nenhum-estado-atinge-a-meta-do-ideb2017-no-ensino-medio/21206; retrieved on 4.10.2018.

INEP (2019) Sinopse Estatística da Educação Básica 2018. Notas Estatísticas. Brasília: INEP.

INEP (n.d.) SAEB. Available at: http://portal.inep.gov.br/web/guest/educacao-basica/saeb; retrieved on 28.5.2019. 
Jarke, J.; Breiter, A. (2019) Editorial: the datafication of education. Learning, Media and Technology, 44(1), 1-6.

Kauko, J.; Centeno, V. G.; Candido, H.; Shiroma, E.; Klutas, A. (2016) The emergence of quality assessment in Brazilian basic education. European Educational Research Journal, 15(5), 558-579.

Kauko, J.; Takala, T.; Rinne, R. (Eds.) Politics of Quality in Education: A Comparative Study on Brazil, China, and Russia. London: Routledge, 137-160.

Kickert, W. (1995) Steering at a Distance: A New Paradigm of Public Governance in Dutch Higher Education. Governance: An International Journal of Policy and Administration, 8(1), 135-157.

Lascoumes, P.; Le Galès, P. (2007) Understanding public policy through its instruments from the nature of instruments to the sociology of public policy instrumentation. Governance, 20(1), 1-21.

Lawn, M. (2011) Governing through Data in English Education. Education Inquiry, 2(2), 277-288.

Lawn, M.; Grek, S. (2012) Europeanizing Education: governing a new policy space. Oxford: Symposium Books.

Lawn, M.; Segerholm, C. (2011). Europe through experts and technologies. In: Ozga, J.; Dahler-Larsen, P.; Segerholm, C.; Simola, H. (eds.) Fabricating quality in education. Data and governance in Europe. London: Routledge, 32-46.

Lingard, B.; Martino, W.; Rezai-Rashti, G.; Sellar, S. (2016) Globalizing Educational Accountabilities. New York; London: Routledge.

Löwenheim, O. (2008) Examining the State: a Foucauldian Perspective on International 'Governance Indicators'. Third World Quarterly, 29(2), 255-274. 
Machado, C.; Alavarse, O. M. (2014) Qualidade das escolas: tensões e potencialidades das avaliações externas. Educação \& Realidade, 39(2), 413-436.

Maguire, M.; Braun, A.; Ball, S. J. (2015) 'Where you stand depends on where you sit': the social construction of policy enactments in the (English) secondary school. Discourse: Studies in the Cultural Politics of Education, 36(4), 485-499.

Maroy, C. (2009) Convergences and hybridization of educational policies around 'postbureaucratic' models of regulation. Compare, 39(1), 71-84.

Maroy, C.; Mathou, C.; Vaillancourt, S. (2017) El profesorado quebequense frente a la 'gestión basada em resultados'. Un estudio cualitativo en cuatro Centros de Secundaria. Revista de Sociología de la Educación, 10(3), 519-538.

Miller, P.; Rose. N. (1990) Governing economic life. Economy and Society, 19(1), 1-31.

Nóvoa, A.; Yariv-Mashal, T. (2003) Comparative research in education: a mode of governance or a historical journey? Comparative Education, 39(4), 423-438.

Oliveira, R. P. de; Araujo, G. C. de. (2005) Qualidade do ensino: uma nova dimensão da luta pelo direito à educação. Revista Brasileira de Educação, 28, 5-24.

Ozga, J. (2009) Governing education through data in England: from regulation to selfevaluation. Journal of Education Policy, 24(2), 261-272.

Ozga, J. (2000) Policy Research in Educational Settings: Contested Terrain. Buckingham: Open University Press.

Ozga, J.; Dahler-Larsen, P.; Segerholm, C.; Simola, H. (eds.) (2011) Fabricating quality in education. Data and governance in Europe. London: Routledge.

Palonen, K. (2003) Four Times of Politics. Alternatives, 28, 171-186. 
Piattoeva, N (2015) Elastic Numbers: National Examinations Data as a Technology of Government. Journal of Education Policy 30(3), 316-34.

Piattoeva, N.; Centeno, V. G.; Suominen, O.; Rinne, R. (2018) Governance by data circulation? The production, availability, and use of national large-scale assessment data. In: Kauko, J.; Takala, T.; Rinne, R. (Eds.) Politics of Quality in Education: A Comparative Study on Brazil, China, and Russia. London: Routledge, 115-136.

Popkewitz, T. S.; Lindblad, S. (2001) Estatísticas educacionais como um sistema de razão: relações entre governo da educação e inclusão e exclusão sociais. Educação \& Sociedade, 22(75), 111-148.

Rose, N.; Miller, P. (1992) Political Power beyond the State. British Journal of Sociology, 43, 173-205.

Ruppert, E.; Isin, E.; Bigo, D. (2017) Data politics. Big Data \& Society, 2017 (Jul-Dec), 1-7.

Schriewer, J.; Martinez, C. (2004) Constructions of internationality in education. In: SteinerKhamsi, G. (2004) The Politics of Educational Borrowing and Lending. New York: Teachers College Press, 29-53.

Simola, H.; Rinne, R.; Varjo, J.; Pitkänen; H.; Kauko, J. (2009) Quality assurance and evaluation (QAE) in Finnish compulsory schooling: a national model or just unintended effects of radical decentralisation? Journal of Education Policy, 24(2), 163-178.

Steiner-Khamsi, G. (2012) The global/local nexus in comparative policy studies: Analysing the triple bonus system in Mongolia over time. Comparative Education, 48(4), 455471.

Steiner-Khamsi, G. (2003) The politics of league tables. Online Journal for Social Sciences and their Didactics, 1, 1-6. 
Tyack, D.; Cuban, L. (1995) Tinkering toward Utopia. A Century of Public School Reform. Cambridge, Massachusetts: Harvard University Press.

UNESCO (2012) International Standard Classification of Education - ISCED 2011. Montreal: UNESCO Institute for Statistics.

UNESCO (2004) The quality imperative. EFA Global Monitoring Report 2005. Paris: UNESCO Publishing.

Weber, M. (2015) Bureaucracy. In Waters, T.; Waters, D. (eds.) Weber's Rationalism and Modern Society: New Translations on Politics, Bureaucracy, and Social Stratification. Hampshire: Palgrave MacMillan, 73-127.

Williamson, B. (2017) Big Data in Education: the digital future of learning, policy and practice. London: SAGE. 